\author{
dr Agnieszka KOZERA \\ Wydział Ekonomiczno-Społeczny, Uniwersytet Przyrodniczy w Poznaniu \\ e-mail: akozera@up.oznan.pl.
}

DOI: $10.15290 /$ ose.2016.04.82.10

\title{
TYPOLOGIA MIAST NA PRAWACH POWIATU WEDLUG POZIOMU ZADLUŻENIA W POLSCE, W LATACH 2007-2014
}

\begin{abstract}
Streszczenie
Miasta na prawach powiatu, ze względu na ich dualny charakter, pełnią funkcje przypisane nie tylko gminom, ale również część zadań przynależnych powiatom. Realizują one zatem szereg zadań zarówno w sferze socjalnej, społecznej, jak i infrastrukturalnej, które mają wpływ na poziom rozwoju społeczno-gospodarczego regionu, oraz jakość życia społeczności lokalnej. Jednak z roku na rok dynamicznie wzrasta zadłużenie podmiotów sektora samorządowego, a w szczególności największych miast na prawach powiatu - metropolii. W 2007 roku zadłużenie ogółem miast na prawach powiatu wyniosło bowiem 11,2 mld zł (7 mld zł w przypadku metropolii), natomiast w 2014 roku było już prawie trzykrotnie wyższe i wzrosło do blisko 32,5 mld zł (w przypadku metropolii do ponad $20 \mathrm{mld}$ zł), stanowiąc ponad 45\% zadłużenia ogółem sektora samorzadowego w Polsce. Analiza zjawiska zadłużenia podmiotów sektora samorządowego, w tym miast na prawach powiatu, z uwagi na to, że realizują one szeroki zakres zadań, a ich dług obejmuje część długu publicznego, $\mathrm{ma}$ istotne znaczenie nie tylko $\mathrm{z}$ racji prawidłowego ich funkcjonowania, ale także bezpieczeństwa finansowego państwa. Głównym celem artykułu jest analiza zjawiska zadłużenia miast na prawach powiatu w Polsce, w latach 2007-2014. Badania przeprowadzono przede wszystkim na podstawie baz danych publikowanych przez Ministerstwo Finansów (W skaźniki do oceny sytuacii finansowej jednostek samorz̨adu terytorialnego) z wykorzystaniem metod statystyki opisowej i metody Warda.
\end{abstract}

Słowa kluczowe: zadłużenie, bezpieczeństwo finansowe, miasta na prawach powiatu, metoda Warda

\section{DEBT OF TOWNS WITH COUNTY STATUS IN POLAND}

\section{Summary}

Due to the dual character of towns with a county status, they function not only as communes but also have some functions of counties. They execute a wide range of welfare-related, social and infrastructural tasks, which affect socio-economic development in the region and quality of life in the local community. Every year the debt of entities in the local government sector increases dynamically. It is particularly noticeable in the biggest towns with the status of counties - metropolises. In 2007, the total debt of towns with a county status was 11.2 billion zlotys (7 billion zlotys in metropolises). In 2014, the debt was nearly three times as great: it increased to nearly 32.5 billion zlotys (more than 20 billion zlotys in metropolises). It amounted to more than $45 \%$ of the total debt of the local government sector in Poland. It seems important that analysis of the debt of entities in the local government sector, including towns with a county status, be conducted because they perform a wide range of activities and their debt is part of public debt. Therefore, the analysis is significant not only for a proper functioning of these entities but also for the financial security of the state. The main aim of the paper is to investigate the debt of towns with a county status in Poland 
between 2007 and 2014. The study is chiefly based on databases published by the Ministry of Finance Indicators to Assess the Financial Situation of Local Government Units, and uses descriptive statistics and Ward's method.

Key words: debt, financial security, towns with a county status, Ward's method

JEL: O20, H6, H62, H68, H69, H72

\section{Wstęp}

Miasta na prawach powiatu stanowią filar systemu samorządu terytorialnego w Polsce. Ze względu na ich dualny charakter pełnią one funkcje przypisane nie tylko gminom, ale również część zadań przynależnych powiatom ${ }^{1}$. Realizują zatem szereg ważnych zadań zarówno w sferze: socjalnej, społecznej, jak i infrastrukturalnej, które przesądzają o poziomie codziennego życia zdecydowanej części ludności i mają wpływ na rozwój społeczno-gospodarczy regionu. $\mathrm{Na}$ znaczenie miast na prawach powiatu w realizacji zadań publicznych uwagę zwrócili m.in.: Dylewski i Stasik [2012, s. 49-60] oraz Dolewka [2014, s. 31-41].

Od 2013 roku w Polsce 66 miast posiada status miast na prawach powiatu, w tym 10 miast cechuje się liczbą mieszkańców powyżej 300 tys. (ț.: Warszawa, Kraków, Łódź, Wrocław, Poznań, Gdańsk, Szczecin, Bydgoszcz, Lublin i Katowice). Na terenie miast na prawach powiatu żyje blisko $13 \mathrm{mln}$ ludności, a więc koncentrują one na swoim terenie ponad jedną trzecią ogółu społeczeństwa. Dwanaście z nich, tj.: Białystok, Bydgoszcz, Gdańsk, Katowice, Kraków, Lublin, Łódź, Poznań, Rzeszów, Szczecin, Warszawa i Wrocław zalicza się do jednostek metropolitalnych [por. Unia Metropolii Polskich]. Metropolie te wytwarzaja ponad jedną trzecią PKB w Polsce, a liczba ich mieszkańców stanowi 7,5 mln, czyli blisko jedną piątą ludności ogółem. Ponadto, należy podkreślić, że obszar metropolitalny, który funkcjonuje wokół największych miast na prawach powiatu, przyczynia się do wytworzenia ponad połowy PKB Polski i obejmuje przeszło 40\% mieszkańców kraju [Raport o polskich metropoliach - Poznań, 2015, s. 3].

Realizacja nałożonych na miasta na prawach powiatu zadań i utrzymanie odpowiedniego poziomu świadczonych usług wymaga zabezpieczenia adekwatnego poziomu środków finansowych. Z uwagi na szeroki zakres zadań realizowanych przez te podmioty często nie wystarcza środków pochodzących z dochodów budżetowych na pokrycie wszystkich wydatków zaplanowanych w budżecie. Jednocześnie miasta na prawach powiatu, chcąc podnieść swą atrakcyjność rezydencjalną i inwestycyjną w warunkach obserwowanego od kilku lat zjawiska suburbanizacji, realizują coraz więcej inwestycji współfinansowanych ze środków pochodzących z Unii Europejskiej. W związku z tym, miasta na prawach powiatu w celu realizacji planowanych zadań są zmuszone

1 Prawa powiatu przysługują miastom, które 31 grudnia 1998 roku liczyły więcej niż 100 tys. mieszkańców, a także tym, które z tym dniem przestały być siedzibami wojewodów ( $\mathrm{z}$ wyjątkiem gdy na wniosek właściwej rady miejskiej odstapiono od nadania miastu praw powiatu) lub którym nadano status miasta na prawach powiatu przy dokonaniu pierwszego podziału administracyjnego kraju na powiaty [Ustawa $z$ dnia 5 czerwca 1998 roku..., art. 91]. 
do uzupełniania brakujących środków, zazwyczaj poprzez zaciąanie kredytów i pożyczek. W rezultacie $z$ roku na rok dynamicznie wzrasta zadłużenie tych podmiotów, a w szczególności największych podmiotów - metropolii. W 2007 roku zadłużenie ogółem miast na prawach powiatu wyniosło bowiem 11,2 $\mathrm{mld} \mathrm{zł}(7 \mathrm{mld}$ zł w przypadku metropolii), natomiast w 2014 roku było już prawie trzykrotnie wyższe i wzrosło do blisko 32,5 mld zł (w przypadku metropolii do ponad $20 \mathrm{mld}$ zl) [Wskaźniki do oceny sytuacji finansowej..., 2007, 2014]. Stanowiło ono więc ponad 45\% zadłużenia ogółem całego sektora samorządowego [Zadtużenie sektora finansów publicznych I kw./2016, 2016]. Analiza zjawiska zadłużenia tych podmiotów, z uwagi na to, że obejmuje ono część długu publicznego, ma istotne znaczenie nie tylko z racji prawidłowego funkcjonowania danej JST, ale także bezpieczeństwa finansowego państwa. Jak zauważył bowiem Dolewka [2014, s. 32-39], problem ten jest bardzo istotny, bowiem rosnace zadłużenie miast na prawach powiatu, w tym metropolii, jest równocześnie realnym zagrożeniem w odniesieniu do wykorzystania nowych środków unijnych, a więc rozwoju lokalnego.

Celem głównym artykułu jest analiza zjawiska zadłużenia miast na prawach powiatu w Polsce, w latach 2007-2014. Badania przeprowadzono na podstawie baz danych publikowanych przez Ministerstwo Finansów [Wskaźniki do oceny sytuacji finansowej jednostek samorzadu terytorialnego] oraz Główny Urząd Statystyczny [Bank Danych Lokalnych]. Zgromadzony materiał empiryczny przetworzono z wykorzystaniem podstawowych metod statystyki opisowej (klasycznych i pozycyjnych) (I etap badań) oraz metod taksonomicznych (metody Warda) z wykorzystaniem programu Statistica (II etap badań).

\section{Metody badawcze}

Badania dotyczące zjawiska zadłużenia miast na prawach powiatu $(N=66)$ w Polsce zrealizowano na dwóch etapach. Na pierwszym, z wykorzystaniem podstawowych metod statystyki opisowej, przeprowadzono analizę poziomu, struktury oraz dynamiki zmian poziomu zadłużenia miast na prawach powiatu w Polsce, w latach 2007-2014. Do oceny skali zjawiska zadłużenia badanych jednostek samorządu terytorialnego (JST) brano pod uwagę wskaźniki, takie jak: poziom zadłużenia ogółem w złotych per capita, udział zadłużenia ogółem w dochodach ogółem (\%) oraz obciążenie dochodów ogółem wydatkami na obsługę zadłużenia (w \%). Aby ukazać zróżnicowanie występujące w zakresie skali zjawiska zadłużenia, a także jego zmian w 2014 roku w relacji do 2007 roku wśród miast na prawach powiatu w Polsce, na drugim etapie badań zrealizowano wielowymiarową analizę zjawiska zadłużenia tych jednostek z wykorzystaniem metody Warda. Analiza taksonomiczna pozwala na ocenę zróżnicowania badanych obiektów (miast na prawach powiatu), opisanych za pomocą zestawu cech diagnostycznych. Prowadzi ona do określenia skupisk tychże obiektów pod względem podobieństwa rozwoju, jak również do otrzymania jednorodnych klas obiektów ze uwagi na charakteryzujące je właściwości [Wysocki, s. 19-23]. Ze względu na zjawisko zadłu- 
żenia analizę typologiczną miast na prawach powiatu przeprowadzono na poniżej wymienionych etapach.

Etap 1. Dokonanie doboru cech cząstkowych zjawiska zadłużenia na podstawie przesłanek merytorycznych i statystycznych.

Etap 2. Przeprowadzenie normalizacji wartości cech diagnostycznych za pomocą standaryzacji klasycznej [Wysocki, 2010, s. 49]:

$$
z_{i k}=\frac{x_{i k}-\bar{x}_{k}}{s_{k}},
$$

gdzie:

$x_{i k}$ - wartość $k$-tej cechy w $i$-tym obiekcie (miasto na prawach powiatu) $(i=N$, $k=1, \ldots, K)$,

$\bar{x}_{k}-$ średnia arytmetyczna $k$-tej cechy,

$s_{k}$ - odchylenie standardowe $k$-tej cechy.

Etap 3. Przeprowadzenie klasyfikacji miast na prawach powiatu za pomoca metody Warda. Hierarchiczna analiza skupień polega na łączeniu najbliższych w stosunku do siebie jednostek, aż do uzyskania jednego skupienia. Dla oszacowania odległości między jednostkami wykorzystuje ona analizę wariancji, zmierzając do minimalizacji sumy kwadratów odchyleń wewnątrz skupień [Stanisz, 2007, s. 122]. Analizie poddano wykres przebiegu aglomeracji celem określenia liczby klas.

Etap 4. Konstruowanie typów zadłużenia miast na prawach powiatu i ich identyfikacja. Identyfikacja typu polega na określeniu podstawowych statystyk opisowych - średnich wewnątrzklasowych, a następnie wyodrębnieniu cech charakterystycznych w klasach typologicznych. W tym celu zastosowano pseudotest róšnic średnich. Wartością tego testu jest wielkość [Wysocki, 2010, s. 139]:

$$
t_{c k(d)}=\frac{\bar{x}_{c k}-\bar{x}_{k}}{s_{c k}} .
$$

Wartość tego testu mierzy odległość między średnią klasową $\left(\bar{x}_{c k}\right)$ a średnią ogólną $\left(\bar{x}_{k}\right)$ k-tej cechy w jednostkach błędu standardowego średniej klasowej, gdzie [Wysocki, 2010, s. 139]:

$s_{c k}^{2}=\frac{N-N_{c}}{N-1} \cdot \frac{s_{k}^{2}}{N_{c}}-$ jest wariancją średniej w przypadku losowania zależnego (bez

zwracania) $N_{c}$ obiektów $c$-tej klasy $(c=1, \ldots, C)$,

$s_{k}^{2}$-jest wariancją empiryczną $k$-tej cechy w zbiorowości,

$\frac{N-N_{c}}{N-1}-$ jest tzw. poprawką na zbiorowości skończonej $N$.

Rozkład średnich klasowych aproksymuje się za pomocą rozkładu normalnego (przy współczynniku ufności 0,95 ), dlatego też przyjmuje się, że wartość średniej danej cechy w klasie nie różni się od średniej ogólnej w granicach od -1,96 do +1,96 błędu standardowego średniej. Takiej cechy nie traktuje się jako charakterystycznej. Im większa jest wartość bezwzględna testu przypisana danej cesze, tym bardziej cecha jest cha- 
rakterystyczna. Wartości pseudotestu różnic średnich były podstawą do wyróżnienia cech charakterystycznych $\mathrm{w}$ klasach typologicznych z wykorzystaniem następującej skali wartości [Wysocki, 2010, s. 139-140]:

1. $t_{c k(d)} \in(-\infty ;-3>\cup<3 ;+\infty)$ - występuje bardzo duże natężenie $k$-tej cechy $\mathrm{w} c$-tej klasie, cecha jest wysoce charakterystyczna (negatywnie lub pozytywnie);

2. $t_{c k(d)} \in(-3 ;-2>\cup<2 ; 3)$-występuje duże natężenie $k$-tej cechy w $c$-tej klasie, cecha jest średnio charakterystyczna (negatywnie lub pozytywnie);

3. $t_{c k(d)} \in(-2 ; 2)$-występuje przeciętne natężenie $k$-tej cechy w $c$-tej klasie, cecha nie wyróżnia się i nie jest charakterystyczna.

\section{Zadłużenie miast na prawach powiatu w Polsce, w latach 2007-2014}

Przesłanką podjęcia problematyki gospodarki finansowej w zakresie zadłużenia JST był dynamiczny wzrost długu publicznego sektora samorządowego na przestrzeni ostatnich lat. W 2007 roku jego zadłużenie w Polsce wyniosło 24,5 mld zł, co stanowiło 4,6\% państwowego długu publicznego, natomiast w 2014 roku wzrosło ono już do 71,7 mld zł, stanowiąc już blisko 8,7\% całkowitego długu publicznego. W rezultacie, $z$ uwagi na wzrost relacji państwowego długu publicznego do PKB (z 44,4\% na koniec 2007 roku do 47,8\% na koniec 2014 roku), przyrost zadłużenia sektora samorządowego ma istotne znaczenie [Zadtuìenie sektora finansón publicznych I kw. / 2016, 2016].

W badanym okresie (od 2007 roku do 2014 roku) dynamicznie rosło zadłużenie ogółem zarówno sektora samorządowego, jak i poszczególnych jego szczebli. Najwyższy poziom zadłużenia ogółem w złotych per capita wśród JST cechował miasta na prawach powiatu, a w szczególności metropolie (tabela 1.). W 2014 roku zadłużenie miast na prawach powiatu ogółem wyniosło 2 019,47 zł na mieszkańca, zaś metropolii było o blisko połowę wyższe i stanowiło 2946,4 zł na mieszkańca. Najniższym poziomem zadłużenia wyróżniały się województwa (165,1 zł per capita) oraz powiaty (222,6 zł per capita w 2014 roku). Jednak należy podkreślić, że realizowały one znacznie mniejszy zakres zadań w odniesieniu do samorządów gminnych i miast na prawach powiatu. W 2014 roku w stosunku do 2007 roku najwyższe średnioroczne tempo zmian poziomu zadłużenia ogółem charakteryzowało metropolie oraz gminy wiejskie i wyniosło odpowiednio: 19,7\% i 18,1\%. W badanym okresie zadłużenie największych miast na prawach powiatu wzrosło ponad trzyipółkrotnie (z 838,9 zł w 2007 roku do 2946,4 zł per capita w $2014 \mathrm{roku}$ ), tymczasem gmin wiejskich ponad trzykrotnie (z 267,7 zł w 2007 roku do 859,1 zł per capita w 2014 roku) (tabela 1.).

Przeprowadzone badania wykazały, że dług odgrywa coraz większą rolę w budżetach zarówno miast na prawach powiatu, jak i w innych podmiotach sektora samorządowego, co wynika z kilku przyczyn. Po pierwsze, wydatki z racji zaspokajania licznych potrzeb społeczności lokalnych przekraczają dochody. Po drugie, zwłaszcza w perspektywie finansowej 2007-2013, wysoka dynamika wzrostu zadłużenia to efekt uruchamiania inwestycji współfinansowanych z funduszy Unii Europejskiej. Zasada współfinanso- 
wania i ograniczenie wkładu finansowego funduszy na realizację projektów generujących przychody netto wiąże się z koniecznościa ponoszenia przez podmioty sektora samorządowego znacznych wydatków finansowanych ze środków własnych bądź pożyczkowych.

TABELA 1.

Poziom zadłużenia jednostek samorządu terytorialnego w Polsce, w latach 2007-2014 (w zł per capita, mediana)

\begin{tabular}{|c|c|c|c|c|c|c|c|c|c|}
\hline Wyszczególnienie & 2007 & 2008 & 2009 & 2010 & 2011 & 2012 & 2013 & 2014 & $\begin{array}{c}\text { Średnioroczne } \\
\text { tempo zmian } \\
(\mathbf{w} \%)^{\mathrm{a})}\end{array}$ \\
\hline Gminy wiejskie & 267,7 & 267,7 & 368,6 & 739,5 & 897,8 & 873,5 & 845,4 & 859,1 & 18,1 \\
\hline Gminy miejsko-wiejskie & 392,9 & 400,6 & 566,0 & 900,9 & 1060,5 & 1051,5 & 1039,3 & 1064,7 & 15,3 \\
\hline Gminy miejskie & 426,9 & 439,3 & 622,9 & 859,9 & 987,9 & 997,3 & 1008,2 & 1021,6 & 13,3 \\
\hline Powiaty & 93,5 & 96,5 & 144,9 & 213,5 & 239,4 & 224,6 & 212,2 & 222,6 & 13,2 \\
\hline Miasta na prawach powiatu & 680,0 & 802,4 & 1133,1 & 1461,0 & 1723,3 & 1871,6 & 1899,2 & 2019,4 & 16,4 \\
\hline $\begin{array}{l}\text { Miasta na prawach powiatu } \\
\text { (bez metropolii) }\end{array}$ & 679,1 & 714,8 & 1119,0 & 1411,1 & 1678,9 & 1683,2 & 1730,0 & 1919,1 & 16,0 \\
\hline Metropolie b) & 838,9 & 1004,5 & 1531,2 & 1912,1 & 2221,4 & 2552,0 & 2828,9 & 2946,4 & 19,7 \\
\hline Województwa & 52,0 & 36,6 & 60,3 & 109,5 & 145,9 & 163,2 & 175,7 & 165,1 & 17,9 \\
\hline
\end{tabular}

a) Obliczone na podstawie dwóch skrajnych wyrazów szeregu czasowego [Wysocki, Lira, 2003, s. 134].

b) Obejmują miasta: Białystok, Bydgoszcz, Gdańsk, Katowice, Kraków, Lublin, Lódź, Poznań, Rzeszów, Szczecin, Warszawa i Wrocław.

Źródło: obliczenia własne na podstawie danych pochodzących z Ministerstwa Finansów: [Wskaźniki do oceny sytuacii finansowej...].

Przeprowadzone badania wykazały, że w 2014 roku w stosunku do 2007 roku dynamicznie wzrosła relacja zadłużenia ogółem wszystkich szczebli sektora samorządowego do dochodów ogółem, zwłaszcza miast na prawach powiatu (o ponad 20,0 p.p.) i metropolii (o blisko 30,0 p.p.). W 2014 roku udział zobowiązań ogółem w dochodach ogółem miast na prawach powiatu równał się $42,4 \%$, przy wartości mediany dla gmin miejskich wynoszącej $31,7 \%$. Biorąc pod uwagę największe miasta na prawach powiatu metropolie, w 2014 roku ich zadłużenie ogółem w dochodach ogółem stanowiło ponad 50\%, tj. o 10 p.p. więcej w stosunku do mediany dla ogółu miast na prawach powiatu (rysunek 1.). Najwyższy wzrost zadłużenia sektora samorządowego i miast na prawach powiatu w badanym okresie odnotowano w latach 2009-2011. W 2009 roku w stosunku do 2008 roku najwyższy wzrost relacji zadłużenia ogółem do dochodów ogółem zaobserwowano w przypadku metropolii (o 16,1 p.p.), ogółu miast na prawach powiatu (o 9,7 p.p.) oraz gmin miejskich (o 9,1 p.p.). W 2011 roku w stosunku do 2010 roku najwyższy jego wzrost odnotowano natomiast w przypadku metropolii (o 7,7 p.p.). Jak zauważyła Poniatowicz i inni [2010, s. 38] oraz Standar [2013, s. 230] sytuacja ta wynikała $z$ chęci realizacji inwestycji współfinansowanych ze środków pochodzacych z Unii Europejskiej w warunkach osłabienia, na skutek kryzysu gospodarczego, koniunktury gospodarczej w Polsce, a w rezultacie w sytuacji zmniejszaja- 
cych się dochodów własnych. Ważne były także, jak podkreślił Jóźwiak [2014, s. 10], nowe wydatki związane z powierzaniem jednostkom samorządowym dodatkowych zadań, którym towarzyszyły niewystarczające dochody i niedoszacowanie obecnie wykonywanych zadań. Jednostki samorządu terytorialnego były zatem zmuszone sięgać po instrumenty dłużne.

\section{Udział zobowiązań ogółem w dochodach ogółem jednostek samorządu terytorialnego w Polsce, w latach 2007-2014 (w \%, mediana)}

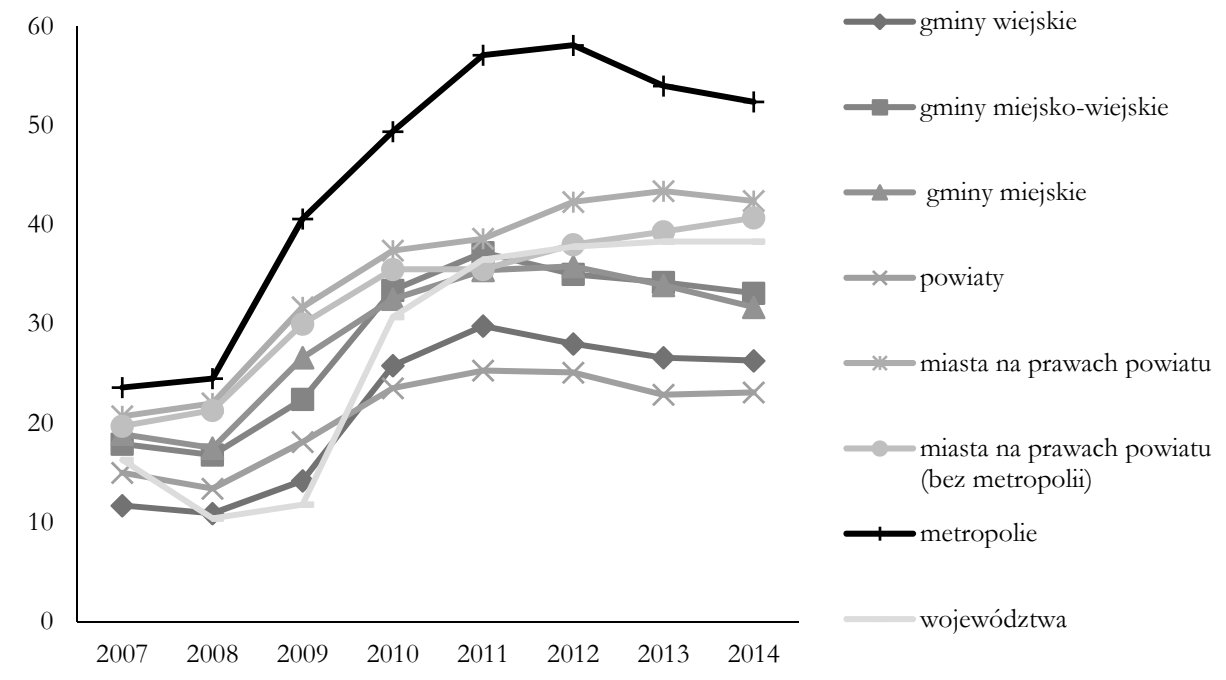

Źródło: opracowanie własne na podstawie danych pochodzących z Ministerstwa Finansów: [Wskaśniki do oceny sytuacii finansowej...].

Przeprowadzone badania wykazały, że w 2014 roku w stosunku do 2007 roku wzrósł przeciętny poziom zadłużenia ogółem miast na prawach powiatu, jednocześnie zwiększyło się zróżnicowanie tych podmiotów w omawianym zakresie (rysunek 2.). W 2007 roku najniższą wysokość zadłużenia ogółem, wynoszącą 39,0 zł per capita, zaobserwowano w Tychach, najwyższą natomiast - 1 875,4 zł per capita w Krakowie (rozstęp wyniósł więc 1 836,5 zl per capita). W 2014 roku w stosunku do 2007 roku rozstęp między najniższą a najwyższą wielkością zadłużenia ogółem miast na prawach powiatu wzrósł blisko dwuipółkrotnie i wyniósł 4 490,4 zł na mieszkańca. Najniższą wysokość zadłużenia, stanowiącą 337,7 zł per capita, odnotowano w Jastrzębiu-Zdroju, najwyższą - 4 828,1 zł per capita $\mathrm{w}$ Toruniu. O rosnącym zróżnicowaniu miast na prawach powiatu w omawianym zakresie świadczy rosnąca wartość rozstępu międzykwartylowego, która w 2007 roku wyniosła 581,6 zł, zaś w 2014 roku już ponad 1375 zł na mieszkańca.

W 2007 roku mediana poziomu zadłużenia ogółem miast na prawach powiatu wyniosła 680 zł, tymczasem w 2014 roku już blisko 2020 zł na mieszkańca. W 2007 roku w przypadku blisko 70\% ogółu miast na prawach powiatu zadłużenie ogółem nie prze- 
kroczyło 1000 zł per capita. W 2014 roku tylko w siedmiu miastach (Jastrzębie-Zdrój, Rybnik, Piekary Śląskie, Sosnowiec, Chorzów, Siemianowice Śląskie, Bytom, stanowiących 10,6\% ogółu miast na prawach powiatu) zadłużenie ogółem nie przekroczyło tej granicy. W przypadku dziesięciu miast na prawach powiatu (Przemyśl, Bydgoszcz, Sopot, Lublin, Warszawa, Wrocław, Łódź, Płock, Wałbrzych, Toruń) poziom zadłużenia ogółem ponad 3000 zł, a w przypadku dwóch miast (Wałbrzycha i Torunia) $4000 \mathrm{zł}$ per capita [Wskaźniki do oceny sytuacii finansowej...].

RYSUNEK 2.

Wykres ramka-wąsy dla wysokości zadłużenia ogółem miast na prawach powiatu w Polsce, w latach 2007-2014 (w zł per capita)

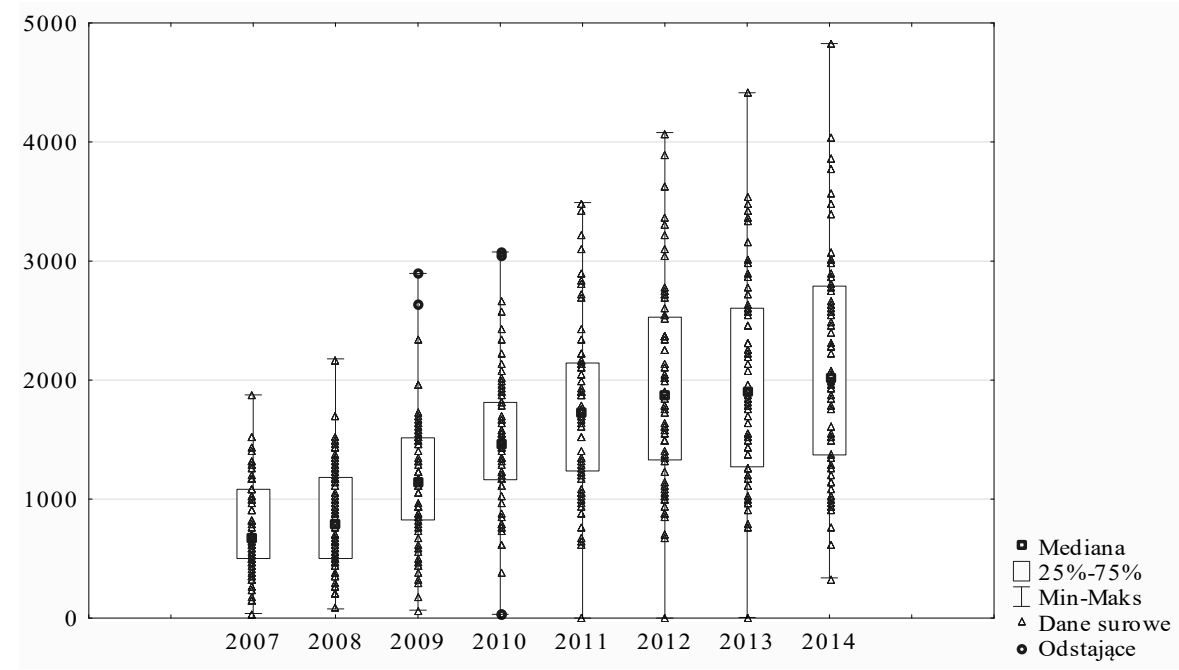

Źródło: opracowanie własne na podstawie danych pochodzących z Ministerstwa Finansów [W skaźniki do oceny sytuacii finansowej...].

Miasta na prawach powiatu są w znacznym stopniu zróżnicowane pod względem: powierzchni, liczby mieszkańców i pełnionych funkcji na rzecz obszarów do nich przyległych. Wśród nich wyróżniają się metropolie, które dysponują ogromnym potencjałem społeczno-gospodarczym. W dwunastu największych miastach na prawach powiatu żyje bowiem 7,5 mln osób (jedna piąta ogółu społeczeństwa), jednocześnie przyczyniaja się one do wytworzenia jednej trzeciej PKB Polski [Raport o polskich metropoliach - Poznań, 2015, s. 3]. Zasięg oddziaływania tych miast na tzw. obszary metropolitalne jest szeroki. W rezultacie ponoszą one dużo wyższe nakłady finansowe na rozwój infrastruktury społecznej i technicznej z uwagi na odmienną skalę potrzeb, która jest pochodną liczby ludności. Z infrastruktury tej (np.: drogowej, komunikacji miejskiej i oświatowej) korzysta nie tylko społeczność lokalna, ale także ludność zamieszkująca obszary metropolitalne. W efekcie przeciętny poziom zadłużenia ogółem metropolii jest dużo wyższy w relacji do pozostałych miast na prawach powiatu. W 2014 roku zadłużenie ogółem przeciętnej metropolii wyniosło 2 946,4 zł na mieszkańca i było 
o połowę wyższe wobec przeciętnej dla miast na prawach powiatu (bez metropolii), które stanowiło 1 919,1 zł na mieszkańca. W 2014 roku w stosunku do 2007 roku metropolie charakteryzowała wyższa dynamika wzrostu zadłużenia w odniesieniu do miast na prawach powiatu (bez metropolii) (tabela 1.).

TABELA 2.

Pozycyjne statystyki opisowe dla poziomu zadłużenia ogółem miast na prawach powiatu w Polsce, w latach 2007-2014 (w zł per capita)

\begin{tabular}{|c|c|c|c|c|c|c|c|c|}
\hline Wyszczególnienie & 2007 & 2008 & 2009 & 2010 & 2011 & 2012 & 2013 & 2014 \\
\hline \multicolumn{9}{|c|}{ Miasta na prawach powiatu (ogółem) } \\
\hline Min & 39,0 & 77,3 & 66,8 & 31,4 & 0,0 & 0,0 & 6,1 & 337,7 \\
\hline Mediana & 680,0 & 802,4 & 1133,1 & 1461,0 & 1723,3 & 1871,6 & 1899,2 & 2019,4 \\
\hline Max & 1875,4 & 2177,6 & 2895,1 & 3075,7 & 3492,2 & 4079,7 & 4413,4 & 4828,1 \\
\hline Rozstęp (max-min) & 1836,5 & 2100,3 & 2828,3 & 3044,3 & 3492,2 & 4079,7 & 4407,2 & 4490,4 \\
\hline $\begin{array}{l}\text { Rozstęp międzykwar- } \\
\text { tylowy }\end{array}$ & 581,6 & 680,2 & 690,4 & 649,9 & 909,6 & 1157,2 & 1307,2 & 1375,7 \\
\hline $\begin{array}{l}\text { Wspó } \\
\text { zmier }\end{array}$ & 42,8 & 42,4 & 30,5 & 22,2 & 26,4 & 30,9 & 34,4 & 34,1 \\
\hline Skoś & 0,39 & 0,12 & 0,11 & 0,08 & $-0,07$ & 0,07 & 0,08 & 0,10 \\
\hline \multicolumn{9}{|c|}{ Miasta na prawach powiatu (bez metropolii) } \\
\hline Min & 39,0 & 77,3 & 66,8 & 31,4 & 0,0 & 0,0 & 6,1 & 337,7 \\
\hline Mediana & 679,1 & 714,8 & 1119,0 & 1411,1 & 1678,9 & 1683,2 & 1730,0 & 1919,1 \\
\hline Max & 1525,3 & 1690,2 & 1966,2 & 2567,8 & 3431,5 & 4079,7 & 4413,4 & 4828,1 \\
\hline Rozstęp ( & 1486,4 & 1612,9 & 1899,5 & 2536,5 & 3431,5 & 4079,7 & 4407,2 & 4490,4 \\
\hline $\begin{array}{l}\text { Rozstęp międzykwar- } \\
\text { tylowy }\end{array}$ & 624,3 & 679,8 & 671,4 & 555,7 & 844,7 & 1013,1 & 1084,9 & 1244,8 \\
\hline $\begin{array}{l}\text { Współczynnik } \\
\text { zmienności }\end{array}$ & 46,0 & 47,6 & 30,0 & 19,7 & 25,2 & 30,1 & 31,4 & 32,4 \\
\hline Skośność & 0,33 & 0,33 & 0,01 & $-0,12$ & $-0,23$ & $-0,11$ & 0,04 & $-0,04$ \\
\hline \multicolumn{9}{|c|}{ Metropolie } \\
\hline Min & 498,2 & 459,1 & 676,0 & 965,0 & 1215,4 & 1578,0 & 1972,0 & 2233,8 \\
\hline Mediana & 838,9 & 1004,5 & 1531,2 & 1912,1 & 2221,4 & 2552,0 & 2828,9 & 2946,4 \\
\hline $\operatorname{Max}$ & 1875,4 & 2177,6 & 2895,1 & 3075,7 & 3492,2 & 3613,3 & 3436,1 & 3765,4 \\
\hline Rozstęp (max-min) & 1377,3 & 1718,5 & 2219,2 & 2110,7 & 2276,8 & 2035,4 & 1464,1 & 1531,6 \\
\hline $\begin{array}{l}\text { Rozstęp międzykwar- } \\
\text { tylowy }\end{array}$ & 443,1 & 499,1 & 738,7 & 774,6 & 913,4 & 740,7 & 503,6 & 911,2 \\
\hline $\begin{array}{l}\text { Współczynnik zmien- } \\
\text { ności }\end{array}$ & 26,4 & 24,8 & 24,1 & 20,3 & 20,6 & 14,5 & 8,9 & 15,5 \\
\hline Skośność & 0,10 & 0,38 & $-0,24$ & $-0,10$ & 0,66 & 0,53 & $-0,06$ & 0,03 \\
\hline
\end{tabular}

Źródło: opracowanie własne na podstawie danych pochodzących z Ministerstwa Finansów [Wskaźniki do oceny sytuacji finansowej...].

W badanym okresie zadłużenie największych miast na prawach powiatu wzrosło bowiem przeciętnie ponad trzyipółkrotnie, natomiast miast na prawach powiatu (bez metropolii) blisko trzykrotnie. W 2014 roku w stosunku do 2007 roku w przypadku 
pięciu metropolii (41,7\% ogółu tych podmiotów), tj. miast: Wrocław, Lublin, Gdańsk, Katowice i Szczecin, zaobserwowano ponad czterokrotny wzrost zadłużenia ogółem. W grupie pozostałych miast na prawach powiatu (bez metropolii) tak wysoki wzrost stwierdzono w odniesieniu do trzynastu miast (24,1\% ogółu tych podmiotów). Najwyższy wzrost zadłużenia ogółem odnotowano m.in. w Sopocie (ponad dziesięciokrotny wzrost, z 264,0 zł w 2007 roku do 3 082,5 zł per capita w 2014 roku) oraz Lomży (blisko dziesięciokrotny wzrost, z 188,7 zł w 2007 roku do 1776,6 zł per capita w 2014 roku) [Wskaźniki do oceny sytuacji finansowej...].

RYSUNEK 3.

Wykres ramka-wąsy dla udziału zadłużenia ogółem w dochodach ogółem miast na prawach powiatu w Polsce, w latach 2007-2014 (w \%)

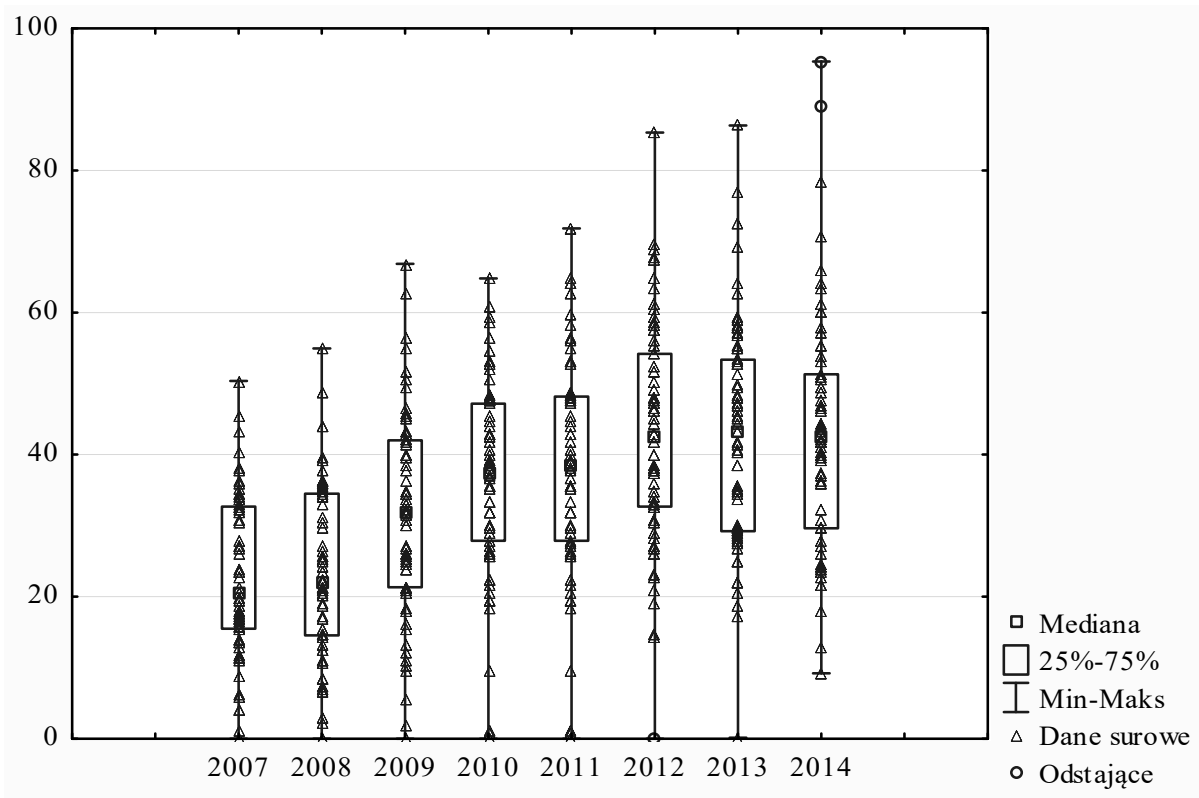

Źródło: opracowanie własne na podstawie danych pochodzących z Ministerstwa Finansów: [Wskaźñiki do oceny sytuacii finansowej...].

Przeprowadzone badania wykazały, że miasta na prawach powiatu (bez metropolii) były w wyższym stopniu zróżnicowane pod kątem poziomu zadłużenia ogółem w stosunku do metropolii, o czym świadczyły wyższe wartości współczynnika zmienności oraz rozstępu międzykwartylowego (tabela 2.). W 2014 roku rozstęp międzykwartylowy poziomu zadłużenia ogółem wyniósł w przypadku miast na prawach powiatu (bez metropolii) 1 244,8 zł, natomiast metropolii 911,2 zł per capita. Jednocześnie należy zauważyć, że w miastach na prawach powiatu (bez metropolii) rozstęp międzykwartylowy w badanym okresie wzrósł o ponad 620 zł, zaś w metropoliach o 468,1 zł na mieszkańca. 
TABELA 3.

Pozycyjne statystyki opisowe dla udziału zadłużenia ogółem w dochodach ogółem miast na prawach powiatu w Polsce, w latach 2007-2014 (w \%)

\begin{tabular}{|c|c|c|c|c|c|c|c|c|}
\hline Wyszczególnienie & 2007 & 2008 & 2009 & 2010 & 2011 & 2012 & 2013 & 2014 \\
\hline \multicolumn{9}{|c|}{ Miasta na prawach powiatu (ogółem) } \\
\hline Min & 0,0 & 0,0 & 0,0 & 0,0 & 0,0 & 0,0 & 0,1 & 9,2 \\
\hline Mediana & 20,7 & 22,0 & 31,7 & 37,4 & 38,6 & 42,3 & 43,4 & 42,4 \\
\hline Max & 50,4 & 54,9 & 66,9 & 64,8 & 71,8 & 85,3 & 86,3 & 95,3 \\
\hline Rozstęp (max-min) & 50,4 & 54,9 & 66,9 & 64,8 & 71,8 & 85,3 & 86,2 & 86,1 \\
\hline $\begin{array}{l}\text { Rozstęp międzykwarty- } \\
\text { lowy }\end{array}$ & 17,0 & 19,8 & 20,6 & 18,6 & 20,0 & 21,0 & 24,0 & 21,3 \\
\hline $\begin{array}{l}\text { Współczynnik zmien- } \\
\text { ności }\end{array}$ & 41,2 & 45,1 & 32,5 & 24,9 & 25,9 & 24,8 & 27,6 & 25,2 \\
\hline Skośność & 0,40 & 0,25 & $-0,01$ & 0,01 & $-0,04$ & 0,09 & $-0,17$ & $-0,17$ \\
\hline \multicolumn{9}{|c|}{ Miasta na prawach powiatu (bez metropolii) } \\
\hline Min & 0,0 & 0,0 & 0,0 & 0,0 & 0,0 & 0,0 & 0,1 & 9,2 \\
\hline Mediana & 19,7 & 21,3 & 30,0 & 35,5 & 35,5 & 38,0 & 39,3 & 40,7 \\
\hline $\operatorname{Max}$ & 50,1 & 48,8 & 56,6 & 64,8 & 64,8 & 85,3 & 86,3 & 95,3 \\
\hline Rozstęp (max- min) & 50,1 & 48,8 & 56,6 & 64,8 & 64,8 & 85,3 & 86,2 & 86,1 \\
\hline $\begin{array}{l}\text { Rozstęp międzykwar- } \\
\text { tylowy }\end{array}$ & 18,7 & 19,2 & 18,6 & 16,4 & 16,4 & 18,3 & 20,4 & 21,8 \\
\hline $\begin{array}{l}\text { Współczynnik zmien- } \\
\text { ności }\end{array}$ & 47,5 & 45,1 & 31,0 & 23,1 & 23,1 & 24,2 & 26,0 & 26,7 \\
\hline Skośność & 0,40 & 0,17 & 0,07 & $-0,10$ & $-0,10$ & 0,17 & $-0,01$ & $-0,24$ \\
\hline \multicolumn{9}{|c|}{ Metropolie } \\
\hline Min & 13,5 & 14,6 & 18,4 & 22,2 & 27,6 & 34,8 & 38,3 & 39,2 \\
\hline Mediana & 23,6 & 24,5 & 40,6 & 49,4 & 57,1 & 58,1 & 54,0 & 52,4 \\
\hline $\operatorname{Max}$ & 50,4 & 54,9 & 66,9 & 60,7 & 71,8 & 68,7 & 72,4 & 78,3 \\
\hline Rozstęp (max-min) & 36,9 & 40,4 & 48,5 & 38,5 & 44,2 & 33,9 & 34,1 & 39,1 \\
\hline $\begin{array}{l}\text { Rozstęp międzykwar- } \\
\text { tylowy }\end{array}$ & 13,9 & 13,6 & 18,5 & 17,6 & 11,0 & 13,5 & 9,4 & 19,9 \\
\hline $\begin{array}{l}\text { Współczynnik zmien- } \\
\text { ności }\end{array}$ & 29,5 & 27,7 & 22,8 & 17,8 & 9,6 & 11,6 & 8,7 & 19,0 \\
\hline Skośność & 0,22 & 0,53 & $-0,21$ & $-0,29$ & 0,06 & $-0,52$ & $-0,03$ & 0,13 \\
\hline
\end{tabular}

Źródło: opracowanie własne na podstawie danych pochodzących z Ministerstwa Finansów: [W skaźniki do oceny sytuacii finansowej...].

Mediana zadłużenia miast na prawach powiatu, pokazane dzięki relacji długu do wykonanych dochodów, w 2014 roku wyniosło 42,4\% i było wyższe niż w 2007 roku o ponad 21,7 p.p. (tabela 3.). Równocześnie w badanym okresie zaobserwowano wzrost rozstępu międzykwartylowego, z 17,0 p.p. w 2007 roku do 21,3 p.p. w 2014 roku. Tym samym w 2014 roku znacznie zwiększyła się liczba miast na prawach powiatu, w przypadku których udział zadłużenia ogółem przekroczył połowę dochodów ogółem. W 2007 roku tylko w dwóch miastach na prawach powiatu, tj.: Kraków i Żory, udział długu w dochodach ogółem stanowił ponad 50\%, natomiast w 2014 roku już 
w 19 miastach (blisko 30\% ogółu tych jednostek), zadłużenie ogółem przekroczyło połowę dochodów ogółem tych jednostek. Należy zauważyć, że od 2009 roku pojawiły się jednostki (i ich liczba w kolejnych latach wzrastała), których dług przekroczył 60\% dochodów ogółem, czyli próg ostrożnościowy poziomu zadłużenia ogółem JST obowiazujący do końca 2013 roku. W 2009 roku były to miasta: Wrocław $(66,9 \%)$ i Kraków (62,7\%), zaś w 2014 roku Torun (95,3\%), Wałbrzych (89,1\%), Łódź (78,3\%), Bydgoszcz (70,6\%), Elblag (66,0\%), Wrocław (64,1\%), Koszalin (60,1\%), Żory (61,3\%), Płock $(60,0 \%)$ oraz Lublin $(63,4 \%)$ [Wskaźniki do oceny sytuacji finansowej...].

RYSUNEK 4.

\section{Wykres ramka-wąsy dla obciążenia dochodów ogółem miast na prawach} powiatu spłatą zadłużenia w Polsce, w latach 2007-2014 (w \%)

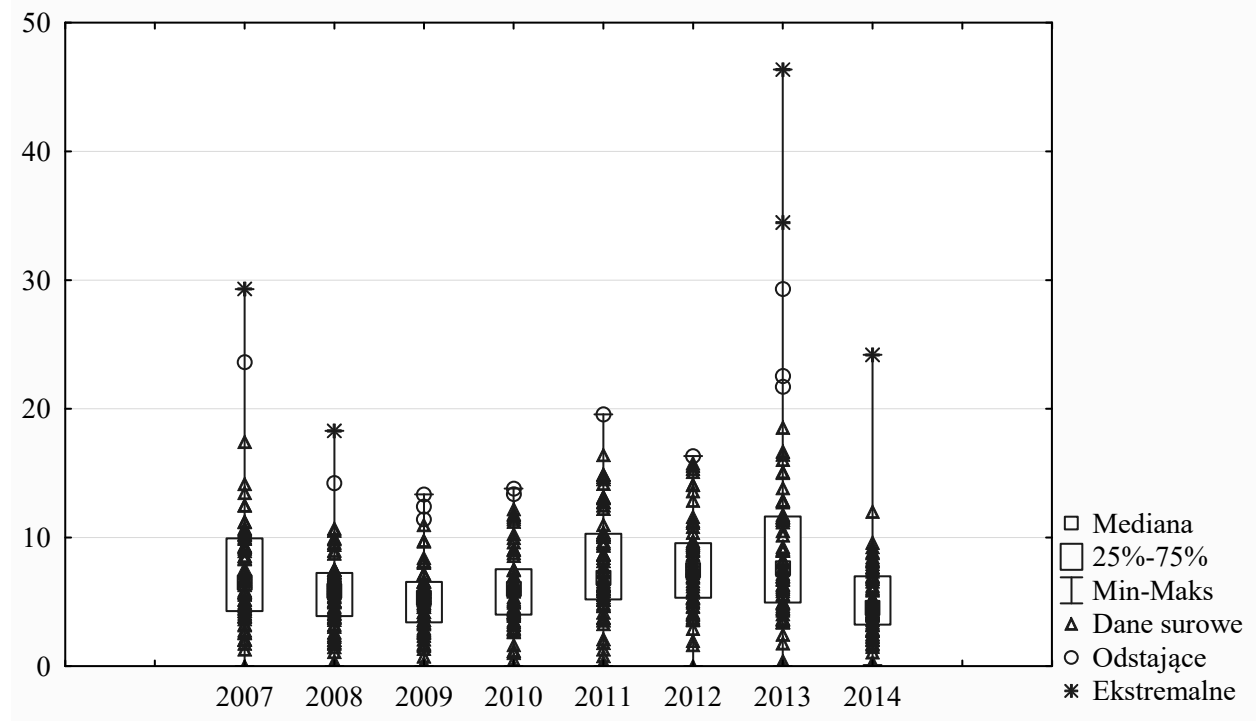

Źródło: opracowanie własne na podstawie danych pochodzących z Ministerstwa Finansów: [Wskaźniki do oceny sytuacii finansowej...].

Wzrost poziomu długu determinuje wyższe koszty związane z jego obsługa, co ma wpływ na zachowanie drugiego progu ostrożnościowego poziomu zadłużenia JST wyznaczonego w Ustawie o finansach publičnych (obowiązującego do 2013 roku), według którego wydatki na obsługę długu nie mogły przekroczyć 15\% dochodów ogółem jednostki samorządowej w danym roku budżetowym. W 2007 roku blisko 6,5\% dochodów ogółem przeciętnego miasta na prawach powiatu w Polsce było obciążone wydatkami na obsługę zadłużenia. Najwyższy poziom obciążenia dochodów ogółem wydatkami na obsługę zadłużenia odnotowano w 2013 roku - 7,6\%, czyli w ostatnim roku unijnej perspektywy finansowej 2007-2013. Tymczasem w 2014 roku obciążenie to nie przekroczyło poziomu 5\% dochodów ogółem. 
TABELA 4.

Pozycyjne statystyki opisowe dla obciążenia dochodów ogółem miast na prawach powiatu wydatkami na obsługę zadłużenia w Polsce, w latach 2007-2014 (w \%)

\begin{tabular}{|c|c|c|c|c|c|c|c|c|}
\hline Wyszczególnienie & 2007 & 2008 & 2009 & 2010 & 2011 & 2012 & 2013 & 2014 \\
\hline \multicolumn{9}{|c|}{ Miasta na prawach powiatu (ogółem) } \\
\hline Min & 0,0 & 0,0 & 0,0 & 0,0 & 0,0 & 0,0 & 0,0 & 0,1 \\
\hline Mediana & 6,5 & 5,8 & 5,3 & 6,0 & 6,9 & 7,5 & 7,6 & 4,5 \\
\hline Max & 29,3 & 18,3 & 13,4 & 13,8 & 19,6 & 16,3 & 46,4 & 24,2 \\
\hline Rozstęp (max-min) & 29,3 & 18,3 & 13,4 & 13,8 & 19,6 & 16,3 & 46,4 & 24,1 \\
\hline $\begin{array}{l}\text { Rozstęp międzykwarty- } \\
\text { lowy }\end{array}$ & 5,5 & 3,3 & 3,0 & 3,5 & 5,0 & 4,2 & 6,7 & 3,7 \\
\hline $\begin{array}{l}\text { Współczynnik zmien- } \\
\text { ności }\end{array}$ & 42,5 & 28,0 & 28,6 & 29,1 & 36,7 & 28,0 & 43,7 & 41,2 \\
\hline Skośność & 0,20 & $-0,16$ & $-0,23$ & $-0,13$ & 0,35 & $-0,02$ & 0,20 & 0,31 \\
\hline \multicolumn{9}{|c|}{ Miasta na prawach powiatu (bez metropolii) } \\
\hline Min & 0,0 & 0,0 & 0,0 & 0,0 & 0,0 & 0,0 & 0,0 & 0,1 \\
\hline Mediana & 6,8 & 5,8 & 5,2 & 6,0 & 6,7 & 7,4 & 7,9 & 4,3 \\
\hline $\operatorname{Max}$ & 29,3 & 18,3 & 13,4 & 13,4 & 19,6 & 16,3 & 46,4 & 24,2 \\
\hline Rozstęp (max- min) & 29,3 & 18,3 & 13,4 & 13,4 & 19,6 & 16,3 & 46,4 & 24,1 \\
\hline $\begin{array}{l}\text { Rozstęp międzykwarty- } \\
\text { lowy }\end{array}$ & 6,0 & 3,5 & 3,2 & 3,1 & 4,8 & 4,0 & 7,4 & 3,0 \\
\hline $\begin{array}{l}\text { Współczynnik zmien- } \\
\text { ności }\end{array}$ & 44,6 & 30,3 & 30,5 & 26,0 & 35,9 & 26,7 & 47,1 & 35,5 \\
\hline Skośność & 0,1 & $-0,2$ & $-0,2$ & $-0,3$ & 0,5 & 0,0 & 0,2 & 0,3 \\
\hline \multicolumn{9}{|c|}{ Metropolie } \\
\hline Min & 1,3 & 1,5 & 1,7 & 1,2 & 1,3 & 2,0 & 1,8 & 1,8 \\
\hline Mediana & 5,8 & 5,9 & 5,4 & 6,9 & 7,4 & 8,6 & 7,4 & 6,8 \\
\hline $\operatorname{Max}$ & 10,2 & 9,0 & 12,4 & 13,8 & 14,9 & 15,8 & 15,1 & 9,6 \\
\hline Rozstęp (max-min) & 8,9 & 7,5 & 10,7 & 12,6 & 13,6 & 13,8 & 13,3 & 7,8 \\
\hline $\begin{array}{l}\text { Rozstęp międzykwarty- } \\
\text { lowy }\end{array}$ & 2,8 & 1,4 & 2,9 & 4,9 & 7,0 & 6,3 & 3,5 & 3,0 \\
\hline $\begin{array}{l}\text { Współczynnik zmien- } \\
\text { ności }\end{array}$ & 23,9 & 11,5 & 26,4 & 35,3 & 47,0 & 36,5 & 23,8 & 22,0 \\
\hline Skośność & 0,4 & $-0,4$ & $-0,3$ & 0,2 & 0,3 & $-0,3$ & $-0,4$ & $-0,3$ \\
\hline
\end{tabular}

Źródło: opracowanie własne na podstawie danych pochodzących z Ministerstwa Finansów: [W skaźnilki do oceny sytuacii finansowej...].

W 2014 roku najwyższe obciążenie dochodów wydatkami na ten cel zaobserwowano w: Siedlcach (24,2\%), Grudziądzu (12,0\%) Poznaniu (9,6\%) oraz Żorach (9,3\%). Z kolei, dochody ogółem w najniższym stopniu były obciążone wydatkami na obsługę zadłużenia w takich miastach, jak: Jastrzębie-Zdrój (0,1\%), Gliwice (0,3\%), Bytom $(1,1 \%)$ i Mysłowice $(1,5 \%)$. W 2014 roku wśród metropolii najniższym obciążeniem dochodów ogółem wydatkami na obsługę zadłużenia wyróżniały się Katowice $(1,8 \%)$ 
i Szczecin (2,4\%), najwyższym natomiast Poznań $(9,6 \%)$ i Wrocław $(8,8 \%)$ [W skažniki do oceny sytuacji finansowej...].

W dokumentach przedstawiających sytuację finansową podmiotów sektora samorządowego (uchwały budżetowe, sprawozdania z wykonania budżetu, opinie RIO, wieloletnie prognozy finansowe) brak jest informacji dotyczących zadłużenia spółek komunalnych, których jedynym (lub większościowym) udziałowcem jest miasto. $\mathrm{Na}$ problem ten zwrócili uwagę m.in.: Wojciechowski [2012], Dolewka [2014], Bitner [2014] oraz twórcy raportu Kondycja finansowa spótek komunalnych w Polsce [2014]. Jest to istotna kwestia z uwagi na fakt, że nieujawnione zadłużenie tych podmiotów zniekształca realny stan finansów JST. Jak zauważył Dolewka [2014, s. 32], choć skonsolidowany bilans JST (jeśli jest upubliczniony) zawiera zobowiazzania wszystkich zależnych podmiotów, to nie jest znana struktura zadłużenia danej JST (sprawozdania spółek komunalnych są dostępne tylko dla ich organów). W rezultacie zobowiązania zaciągane przez te podmioty nie powiększają długu publicznego ani długu danej JST. Nie można wykluczyć sytuacji, w której spółki prawa handlowego były zakładane przez JST, aby uniknąc przekroczenia ustawowo (obowiązujących do 2013 roku) ograniczeń poziomu zadłużenia ogólnego. Z kolei, w świetle nowych przepisów prawnych, obowiązujących od 2014 roku, możliwość zaciagania nowych zobowiązań przez JST jest uzależniona od relacji wielkości obsługi długu do nadwyżki operacyjnej osiagniętej w trzech ostatnich latach [Ustawa z. dnia 27 sierpnia 2009 roku ...., art. 243]. Dolewka [2014, s. 35-39] skonstatował, że zdecydowana większość władz największych miast wojewódzkich w latach 2011-2013 podjęła się wykorzystania alternatywnych sposobów realizacji inwestycji i ich finansowania, angażując do tego spółki komunalne. Podobne wyniki badań przedstawiono w raporcie przygotowanym przez Pokrywkę [2011], z którego wynika, że skala działalności spółek komunalnych jest zdecydowanie najwyższa w dużych miastach - metropoliach. W rezultacie takich działań część deficytu budżetowego jest „wypychana" poza budżet miasta. Tymczasem Poniatowicz [2011, s. 24] stwierdziła, że obserwowany proces ,wypychania” długu przez największe miasta na prawach powiatu to raczej przejaw efektywnego zarządzania długiem publicznym aniżeli kreatywnej księgowości. Problem ten jest więc bardzo złożony i wymaga prowadzenia pogłębionych badań.

\section{Klasyfikacja miast na prawach powiatu według zjawiska zadłużenia}

Badania przeprowadzone $z$ wykorzystaniem podstawowych metod statystyki opisowej wykazały występujące znaczne zróżnicowanie wśród miast na prawach powiatu w Polsce w zakresie zjawiska zadłużenia i jego zmian w 2014 roku w stosunku do 2007 roku. Na drugim etapie badań zróżnicowanie zjawiska zadłużenia miast na prawach powiatu zaprezentowano na podstawie wyodrębnionych (za pomocą metody Warda) klas typologicznych. W ich identyfikacji uwzględniono wskaźniki cząstkowe poziomu zadłużenia tych podmiotów w 2014 roku (tij:: poziom zadłużenia ogółem w zł na miesz- 
kańca, udział zadłużenia ogółem w dochodach ogółem (w \%) i obciążenie dochodów ogółem wydatkami na obsługę zadłużenia (w \%)), ale jednocześnie dynamikę zmian zjawiska zadłużenia tych podmiotów w 2014 roku w stosunku do 2007 roku² (tj.: wskaźniki dynamiki zmian poziomu zadłużenia ogółem w zł na mieszkańca $(2007=100 \%)$, zmianę udziału zadłużenia ogółem w dochodach ogółem (w p.p.) oraz zmianę obciążenia dochodów ogółem wydatkami na obsługę zadłużenia (w p.p.) ) 3 .

Badania typologiczne, przeprowadzone $z$ wykorzystaniem metody klasyfikacji rozłącznej (metody Warda), pozwoliły na wyodrębnienie 8 klas typologicznych miast na prawach powiatu, charakteryzujących się zarówno różnym poziomem zjawiska zadłużenia, jak i skala jego zmian w 2014 roku w stosunku do 2007 roku. Wyodrębnione klasy typologiczne opisano za pomoca cech branych pod uwagę w klasyfikacji typologicznej (tzw. cech aktywnych), lecz także wybranych cech społeczno-ekonomicznych (tzw. cech pasywnych). Analizie poddano wybrane klasy typologiczne o najwyższym i najniższym poziomie zjawiska zadłużenia. Cechy charakterystyczne w tych klasach typologicznych (aktywne i pasywne) wyróżniono za pomocą analizy wartości pseudotestu dla średnich ${ }^{4}$.

Badania te wykazały, że wysokim poziomem zjawiska zadłużenia cechowały się miasta na prawach powiatu, które utworzyły: III, IV oraz VII klasę typologiczna, natomiast najwyższą dynamiką zmian zjawiska zadłużenia w 2014 roku w stosunku do 2007 roku charakteryzowało się miasto Tychy, które utworzyło I klasę typologiczną (rysunek 5., tabele: 5. i 6.). Najwyższy poziom zadłużenia ogółem w przeliczeniu na mieszkańca, udział w dochodach ogółem, a równocześnie najwyższe obciążenie dochodów ogółem wydatkami na obsługę zadłużenia objęło 7 miast na prawach powiatu $(10,6 \%$ ogółu tych jednostek), które utworzyły III klasę typologiczna. Poziom zadłużenia ogółem tych miast wyniósł bowiem w 2014 roku przeciętnie 3 736,2 zł per capita, co stanowiło blisko $70 \%$ ich dochodów ogółem. Wysoki poziom zadłużenia w omawianej klasie był pochodną liczby ludności miast, które ją utworzyły, tj. 4 metropolie - Warszawa, Wrocław, Lublin, Łódź oraz miasto Toruń. Najmniejszym miastem, które weszło w skład omawianej klasy, był Sopot (40 tys. mieszkańców). Cechą charakterystyczną tej klasy była wysoka zmiana udziału zadłużenia ogółem w dochodach ogółem w 2014 roku w stosunku do 2007 roku, która wyniosła aż 49 p.p. (przy przeciętnej dla ogółu miast na prawach powiatu wynoszącej 20 p.p.). W badanym okresie, w wyniku wzrostu udziału zadłużenia ogółem w dochodach ogółem, zwiększyło się obciążenie dochodów ogółem omawianych miast obsługa zadłużenia przeciętnie o 3,5 p.p.

2 Tylko w przypadku miasta Wałbrzych, posiadającego status miasta na prawach powiatu od 2013 roku, wskaźniki dynamiki zostały obliczone w stosunku do 2013 roku.

${ }^{3}$ Uwzględniając statystyczne kryteria, do dalszych badań przyjęto wszystkie zaproponowane cechy proste, które charakteryzowały się wysokim potencjałem informacyjnym i niskim skorelowaniem z pozostałymi cechami prostymi.

${ }^{4}$ Zgodnie ze wskazaną metodyką badań, do jego obliczenia wykorzystano wartości średnie, a nie mediany. 


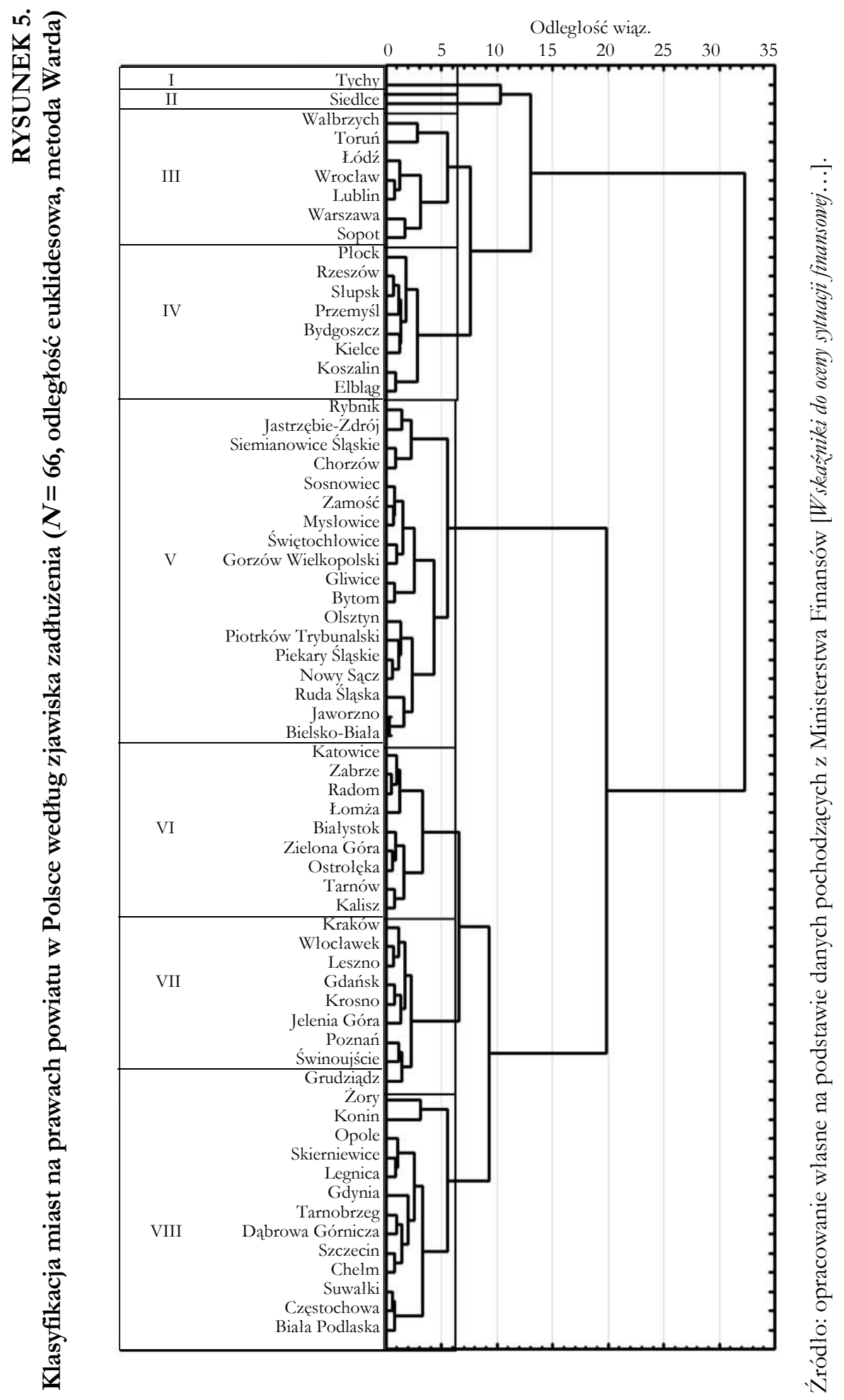


TABELA 5.

Wyniki klasyfikacji miast na prawach powiatu według zjawiska zadłużenia w Polsce, w latach 2007-2014 (wartości przeciętne - mediana)

\begin{tabular}{|c|c|c|c|c|c|c|c|c|c|}
\hline \multirow[t]{2}{*}{ Wyszczególnienie } & \multicolumn{8}{|c|}{ Klasa typologiczna } & \multirow[t]{2}{*}{ Ogółem } \\
\hline & $\mathbf{I}$ & II & III & IV & $\mathbf{V}$ & VI & VII & VIII & \\
\hline Liczba miast & 1 & 1 & 7 & 8 & 20 & 7 & 9 & 13 & 66 \\
\hline Odsetek miast & 1,5 & 1,5 & 10,6 & 12,1 & 30,3 & 10,6 & 13,6 & 19,7 & 100 \\
\hline \multicolumn{10}{|c|}{ Cechy aktywne } \\
\hline $\begin{array}{l}\text { Poziom zadłużenia ogó- } \\
\text { łem (w zł na mieszkańca) }\end{array}$ & 1514,4 & 2803,0 & 3736,2 & 3011,0 & 1136,6 & 2046,5 & 2563,9 & 2010,9 & 2133,8 \\
\hline $\begin{array}{l}\text { Udział zadłużenia ogółem } \\
\text { w dochodach ogółem (w \%) }\end{array}$ & 29,6 & 50,4 & 68,2 & 59,6 & 25,5 & 41,3 & 48,5 & 43,6 & 43,0 \\
\hline $\begin{array}{l}\text { Obciążenie dochodów ogó- } \\
\text { łem spłatą zadłużenia (w \%) }\end{array}$ & 3,3 & 24,2 & 7,7 & 4,0 & 3,6 & 4,9 & 8,2 & 4,2 & 5,3 \\
\hline $\begin{array}{l}\text { Dynamika zmian pozio- } \\
\text { mu zadłużenia ogółem } \\
\text { (w zł na mieszkańca, } \\
2007=100 \% \text { ) }\end{array}$ & $\begin{array}{r}3 \\
885,9\end{array}$ & 340,7 & 489,3 & 398,6 & 306,8 & 340,5 & 228,5 & 267,2 & 377,1 \\
\hline $\begin{array}{l}\text { Zmiana udziału zadłużenia } \\
\text { ogółem w dochodach ogółem } \\
\text { (2014/2007, w p.p.) }\end{array}$ & 28,4 & 22,7 & 49,0 & 35,6 & 8,0 & 20,0 & 14,5 & 16,3 & 20,0 \\
\hline $\begin{array}{l}\text { Zmiana obciążenia docho- } \\
\text { dów ogółem spłatą zadłuże- } \\
\text { nia }(2014 / 2007 \text {, w p.p.) }\end{array}$ & 0,7 & 20,1 & 3,5 & $-3,2$ & $-2,2$ & 1,2 & $-1,7$ & $-8,5$ & $-2,1$ \\
\hline \multicolumn{10}{|c|}{ Cechy pasywne } \\
\hline $\begin{array}{l}\text { Dochody własne (w zł na } \\
\text { mieszkańca) }\end{array}$ & 3010,9 & 3166,4 & 3131,7 & 2041,8 & 2279,6 & 2489,4 & 2969,3 & 2409,9 & 2525,8 \\
\hline $\begin{array}{l}\text { Wydatki inwestycyjne (w } \\
\text { zł na mieszkańca, za okres } \\
2007-2014 \text { ) }\end{array}$ & 10094,8 & 5799,3 & 9997,3 & 4322,0 & 4888,4 & 6184,9 & 7761,8 & 6215,8 & 6274,2 \\
\hline $\begin{array}{l}\text { Finansowanie i współfinan- } \\
\text { sowanie programów i projel } \\
\text { tów unijnych (w zł na miesz } \\
\text { kańca, za okres } 2010-14)^{a)}\end{array}$ & 537,5 & 291,6 & 480,9 & 390,8 & 263,7 & 224,7 & 429,7 & 275,5 & 289,0 \\
\hline $\begin{array}{l}\text { Nadwyżka operacyjna } \\
\text { (w zł na mieszkańca, za } \\
\text { okres 2007-2014) }\end{array}$ & 4761,3 & 1053,2 & 2091,7 & 1623,4 & 1581,1 & 1995,8 & 2833,8 & 2067,5 & 2037,8 \\
\hline $\begin{array}{l}\text { Gęstość zaludnienia (na } \\
\mathrm{km}^{2} \text { ) }\end{array}$ & 1572 & 2404 & 2179 & 1399 & 1633 & 1838 & 1682 & 1238 & 1637 \\
\hline $\begin{array}{l}\text { Podmioty gospodarcze na } \\
10 \text { tys. ludności }\end{array}$ & 1074,6 & 1095,0 & 1295,9 & 1268,0 & 999,3 & 1141,8 & 1540,5 & 1035,3 & 1140,7 \\
\hline
\end{tabular}

a) Brak danych za lata 2007-2009.

Źródło: opracowanie własne na podstawie danych pochodzących z Ministerstwa Finansów: [Wskaźniki do oceny sytuacji finansowej...] oraz z Głównego Urzędu Statystycznego [Bank Danych Lokalnych]. 
TABELA 6.

Wartości miernika pseudotestu różnic średnicha) dla cech w klasach typologicznych miast na prawach powiatu, wyodrębnionych według zjawiska zadłużenia

\begin{tabular}{|c|c|c|c|c|c|c|c|c|}
\hline \multirow[b]{2}{*}{ Wyszczególnienie } & \multicolumn{8}{|c|}{ Klasa typologiczna } \\
\hline & Ic) & IIc) & III & IV & $\mathbf{V}$ & VI & VII & VIII \\
\hline \multicolumn{9}{|c|}{ Cechy aktywne } \\
\hline $\begin{array}{l}\text { Poziom zadłużenia ogółem } \\
\text { (w zł na mieszkańca) }\end{array}$ & $\times$ & $\times$ & 7,9 & 7,3 & $-14,2$ & $-1,3$ & 4,6 & $-1,4$ \\
\hline $\begin{array}{l}\text { Udział zadłużenia ogółem } \\
\text { w dochodach ogółem (w \%) }\end{array}$ & $\times$ & $\times$ & 3,4 & 8,1 & $-11,7$ & $-2,9$ & 3,3 & 0,3 \\
\hline $\begin{array}{l}\text { Obciążenie dochodów ogółem } \\
\text { spłatą zadłużenia (w \%) }\end{array}$ & $\times$ & $x$ & 5,3 & $-2,8$ & $-4,2$ & $-0,5$ & 5,4 & $-2,3$ \\
\hline $\begin{array}{l}\text { Dynamika zmian poziomu za- } \\
\text { dłużenia ogółem (w zł na } \\
\text { mieszkańca, } 2007=100 \% \text { ) }\end{array}$ & $\times$ & $\times$ & 1,0 & 0,4 & $-1,5$ & $-0,8$ & $-5,6$ & $-4,0$ \\
\hline $\begin{array}{l}\text { Zmiana udziału zadłużenia } \\
\text { ogółem w dochodach ogółem } \\
\text { (2014/2007, w p.p.) }\end{array}$ & $\times$ & $\times$ & 4,3 & 5,8 & $-5,0$ & 0,0 & $-2,3$ & $-1,4$ \\
\hline $\begin{array}{l}\text { Zmiana obciążenia dochodów } \\
\text { ogółem spłatą zadłużenia } \\
\text { (2014/2007, w p.p.) }\end{array}$ & $\times$ & $\times$ & 8,6 & $-1,0$ & $-0,1$ & 7,6 & 0,5 & $-4,1$ \\
\hline \multicolumn{9}{|c|}{ Cechy pasywne } \\
\hline $\begin{array}{l}\text { Dochody własne (w zł na miesz- } \\
\text { kańca) }\end{array}$ & $\times$ & $\times$ & 1,2 & $-2,7$ & $-2,9$ & $-0,2$ & 2,2 & $-0,7$ \\
\hline $\begin{array}{l}\text { Wydatki inwestycyjne (w zł na } \\
\text { mieszkańca, za okres 2007-2014) }\end{array}$ & & & 1,7 & $-3,9$ & $-3,0$ & $-0,1$ & 2,5 & $-0,1$ \\
\hline Finansowanie i współfinanso- & $\times$ & $\times$ & & & & & & \\
\hline $\begin{array}{l}\text { Finansowanie i współfinanso- } \\
\text { wanie programów i projektów } \\
\text { unijnych (w zł na mieszkańca, } \\
\text { za okres } 2010-2014)^{\mathrm{b})}\end{array}$ & $\times$ & $\times$ & 2,1 & 1,2 & $-2,9$ & $-1,0$ & 2,0 & $-1,0$ \\
\hline $\begin{array}{l}\text { Nadwyżka operacyjna (w zł na } \\
\text { mieszkańca, za okres 2007-2014) }\end{array}$ & $\times$ & $\times$ & 0,6 & $-0,5$ & $-0,2$ & $-0,9$ & 2,1 & 0,6 \\
\hline Gęstość zaludnienia (na km²) & $\times$ & $x$ & 2,5 & $-2,0$ & 0,0 & 1,2 & 0,2 & $-3,8$ \\
\hline $\begin{array}{l}\text { Podmioty gospodarcze (na } 10 \text { tys. } \\
\text { ludności) }\end{array}$ & $\times$ & $\times$ & 0,9 & 1,5 & $-3,2$ & 0,0 & 3,7 & $-1,5$ \\
\hline
\end{tabular}

a) Odcienie szarości oznaczają wysokie bezwzględne wartości pseudotestu różnic średnich - cechy charakterystyczne (kolory ciemno- i jasnoszary oznaczają odpowiednio wysokie i niskie natężenie k-tej cechy w $c$-tej klasie).

b) Brak danych za lata 2007-2009.

c) Brak możliwości obliczenia wartości tego testu dla klas typologicznych tworzonych przez jeden obiekt.

Źródło: opracowanie własne na podstawie danych pochodzących z Ministerstwa Finansów: [W skaŕniki do oceny sytuacji finansowej...] oraz z Głównego Urzędu Statystycznego [Bank Danych Lokalnych].

Wysoki poziom zadłużenia ogółem charakteryzował także 8 miast na prawach powiatu (12,1\% ogółu tych podmiotów), które utworzyły klasę IV. Przeciętny poziom zadłużenia ogółem tych podmiotów wyniósł 3 011,0 zł per capita w 2014 roku, tj. o blisko 
jedną trzecią więcej w stosunku do przeciętnego miasta na prawach powiatu. Klasę tę na tle pozostałych cechował także wysoki udział zadłużenia ogółem w dochodach ogółem, który wyniósł przeciętnie blisko $60 \%$. Jednak należy podkreślić, że pomimo wzrostu udziału zadłużenia ogółem w dochodach ogółem, miasta te w odróżnieniu do III klasy typologicznej wyróżniał spadek obciążenia dochodów ogółem wydatkami na obsługę zadłużenia o 3,2 p.p. (tabele: 5., 6.). Miasta te w okresie od 2007 roku do 2013 roku zrealizowały znacznie niższe wydatki inwestycyjne w przeliczeniu na mieszkańca w relacji do miast tworzących klasę III. Analizując poziom nadwyżki operacyjnej, można także stwierdzić, że przy jej relatywnie niskim poziomie w relacji do przeciętnej dla ogółu miast na prawach powiatu, w warunkach wysokiego poziomu zadłużenia ogółem, poziom bezpieczeństwa finansowego tych podmiotów był relatywnie niski.

Najniższym poziomem zadłużenia charakteryzowały się miasta na prawach powiatu, które utworzyły klasę V (20 miast, stanowiących 30,3\% ogółu tych podmiotów) (tabele: 5., 6.). Przeciętny poziom zadłużenia tych miast stanowił zaledwie $1136,6 \mathrm{zł}$ per capita, tj. o blisko połowę mniej w stosunku do przeciętnego miasta na prawach powiatu. Niski przeciętny poziom zadłużenia ogółem tych podmiotów przekładał się na niski jego udział w dochodach ogółem, który wynosił tylko jedną czwartą rocznego budżetu. Przeprowadzone badania wykazały, że cechą szczególną dla tej klasy był równocześnie najniższy wzrost udziału zadłużenia ogółem w dochodach ogółem. W 2014 roku w stosunku do 2007 roku udział zadłużenia ogółem w dochodach ogółem wzrósł bowiem w omawianej klasie o 8,0 p.p., podczas gdy w przeciętnym mieście na prawach powiatu aż o 20,0 p.p. Omawianą klasę typologiczną utworzyły głównie najmniejsze miasta na prawach powiatu, gdyż w przypadku połowy z nich liczba mieszkańców nie przekroczyła 100 tys., natomiast tylko jedno miasto, tj. Sosnowiec charakteryzowała liczba ludności powyżej 200 tys. Niski poziom zadłużenia tych podmiotów mógł również wynikać z niższego poziomu samodzielności finansowej, kwantyfikowanej poziomem dochodów własnych $\mathrm{w}$ przeliczeniu na mieszkańca, a także z dużo niższej aktywności inwestycyjnej (tabele: 5., 6.). W latach 2007-2014 miasta tworzące omawianą klasę przeznaczyly na inwestycje 4 888,4 zł, przy przeciętnej dla ogółu miast na prawach powiatu wynoszącej ponad $6270 \mathrm{zl}$ na mieszkańca.

Jednocześnie relatywnie wysokim poziomem zjawiska zadłużenia cechowały się miasta na prawach powiatu, tworzące VII klasę typologiczną ( 9 miast, stanowiących blisko 14\% ogółu tych podmiotów), których zadłużenie ogółem w 2014 roku wyniosło przeciętnie 2 563,9 zł na mieszkańca. Wiele tych miast w 2007 roku, m.in. Poznań, charakteryzował wysoki poziom zadłużenia, a w rezultacie ich widoczną cechą była niska dynamika zmian poziomu zadłużenia ogółem w 2014 roku w relacji do 2007 roku. Miasta te, podobnie jak te tworzące typ III, wyróżniała wysoka samodzielność finansowa i aktywność inwestycyjna, a zarazem wysoka generowana nadwyżka operacyjna. W relacji do pozostałych klas, klasa ta również wyróżniała się w zakresie poziomu środków finansowych pozyskanych z Unii Europejskiej na współfinansowanie projektów inwestycyjnych (tabele: 5. i 6.).

Pierwszą klasę typologiczną utworzyło jedno miasto na prawach powiatu, tj. Tychy. Cechą wyróżniającą tego miasta był nie tylko niższy w relacji do przeciętnego miasta na prawach powiatu zarówno poziom, jak i udział zadłużenia ogółem w dochodach ogó- 
łem, ale przede wszystkim najwyższa dynamika wzrostu zadłużenia ogółem na mieszkańca w 2014 roku w stosunku do 2007 roku. Zadłużenie ogółem miasta Tychy w badanym okresie wzrosło bowiem blisko czterdziestokrotnie (z 39,0 zł w 2007 roku do 1 514,4 zł per capita w 2014 roku). Tak wysoki wzrost poziomu zadłużenia ogółem nie spowodował jednak znacznego wzrostu obciążenia dochodów ogółem analizowanej JST wydatkami na obsługę zadłużenia. Miasto to na tle przeciętnego miasta na prawach powiatu w Polsce wyróżnia się wysokim poziomem samodzielności finansowej, a także wysoką atrakcyjnością finansowa. W okresie od 2007 roku do 2014 roku na wydatki inwestycyjne miasto to przeznaczyło bowiem ponad 10 tys. zł na mieszkańca. Należy przy tym zauważyć, że żadne miasto wojewódzkie nie cechowało się niższym poziomem zadłużenia w relacji do miasta Tychy. Cechą charakterystyczną tego miasta jest jednocześnie wysoki poziom nadwyżki operacyjnej, która pozwala na swobodna spłatę wcześniej zaciagniętych zobowiązań, jak również w warunkach regulacji prawnych obowiązujących od 2014 roku umożliwia zaciaganie nowych zobowiązań (tabele: 5. 6.).

Jedno miasto (Siedlce) utworzyło drugą klasę typologiczna. Cechą charakterystyczną tego miasta jest relatywnie wysoki poziom zadłużenia ogółem, ale przede wszystkim wysokie obciążenie dochodów ogółem wydatkami na obsługę zadłużenia, wynoszące 24,2\% w 2014 roku, przy przeciętnej dla ogółu miast na prawach powiatu stanowiącej $5,3 \%$. Wysoki poziom zadłużenia ogółem omawianego miasta i niski poziom generowanej nadwyżki operacyjnej świadczy o niezbyt korzystnej sytuacji finansowej tej JST (tabele: 5., 6.). Wysokość nadwyżki operacyjnej wskazuje bowiem, jakie są możliwości miasta $\mathrm{w}$ zakresie tworzenia oszczędności z działalności bieżącej i przeznaczenia ich na inwestycje. Niski jej poziom może być dla miasta barierą związaną z pozyskaniem nowych środków finansowych z Unii Europejskiej w obecnej perspektywie finansowej 2014-2020.

\section{Podsumowanie}

Miasta na prawach powiatu, w tym metropolie, ponoszą znacznie wyższe nakłady finansowe na rozwój infrastruktury społecznej i technicznej. Sytuacja ta wynika zarówno z ich dualnego charakteru, jak i odmiennej skali potrzeb, która jest pochodną liczby ludności. W rezultacie zadłużenie miast na prawach powiatu, a w szczególności metropolii, na skutek realizacji szeregu inwestycji rosło szybciej niż pozostałych jednostek samorządu terytorialnego. W 2007 roku zadłużenie ogółem miast na prawach powiatu wyniosło bowiem 11,2 $\mathrm{mld}$ zł ( $7 \mathrm{mld} \mathrm{zł} \mathrm{w} \mathrm{przypadku} \mathrm{metropolii),} \mathrm{natomiast}$ w 2014 roku było już prawie trzykrotnie wyższe i wzrosło do blisko 32,5 mld zł (w przypadku metropolii do ponad 20 mld zł), obejmując ponad 45\% zadłużenia ogółem całego sektora samorządowego w Polsce.

W Polsce miasta na prawach powiatu są różnorodne pod względem posiadanego potencjału demograficznego i gospodarczego, a także w zakresie stopnia oddziaływania na obszary przyległe. W rezultacie zróżnicowanego poziomu samodzielności finansowej, potencjału inwestycyjnego, poziomu rozwoju społeczno-gospodarczego, jak również 
aktywności władz samorządowych w pozyskiwaniu środków unijnych są one w znacznej mierze zróżnicowane w zakresie poziomu zadłużenia, na co wskazały wyniki przeprowadzonej klasyfikacji typologicznej. Co dziesiąte miasto na prawach powiatu w Polsce wyróżnia się zarówno wysokim poziomem i udziałem zadłużenia w dochodach ogółem, jak i znacznym obciążeniem dochodów ogółem wydatkami na obsługę zadłużenia. Są to zwłaszcza metropolie, tj.: Warszawa, Wrocław, Lublin, Łódź, Torun, ale zarazem Wałbrzych i Sopot. Z kolei, niskim poziomem zadłużenia ogółem w przeliczeniu na mieszkańca, niskim jego udziałem w dochodach ogółem, a jednocześnie niskim obciążeniem dochodów ogółem wydatkami na obsługę zadłużenia odznacza się blisko co trzecie miasto na prawach powiatu. Stanowia je miasta o relatywnie niższym potencjale demograficznym i gospodarczym, a więc podmioty o niższym poziomie samodzielności finansowej i mniejszej zdolności do kreowania rozwoju lokalnego.

\section{Literatura}

Bank Danych Lokalnych, Główny Urząd Statystyczny, Warszawa, www.stat.gov.pl/bdl (data wejścia: 14.07.16).

Bitner M., 2014, Spótki prawa handlowego - przeniesienie zadtušenia poza JST, [w:] Zadtużenie jednostek samorzadu terytorialnego. Wyzwania w obliczu nowej perspektywy finansowej UE, P. Walczak (red.), Wydawnictwo C.H. Beck, Warszawa.

Dolewka Z., 2014, Bezpieczeństwo finansowe miast wojewódžkich, „Nierówności Społeczne a Wzrost Gospodarczy", nr 40.

Dylewski M., Stasik B., 2012, Rola $i$ znaczenie miast na prawach powiatu w realizacji zadań publicznych, [w:] Finanse i rysylko w ksztaltowaniu rozwoju regionu, M. Dylewski (red.), Zeszyty Naukowe Wyższej Szkoły Bankowej w Poznaniu, nr 41.

Jóźwiak M., 2014, Pojecie dtugu. Statystyka dlugu publicznego. Metodologia ustalania zadtużenia, [w:] Zadtuizenie jednostek samorzadu terytorialnego, Wyzwania w obliczu nowej perspektywy finansowej UE, P. Walczak (red.), Wydawnictwo C.H. Beck, Warszawa.

Kondycja finansowa spótek. komunalnych w Polsce, 2014, Curulis, Doradztwo Samorządowe, www.curulis.pl (data wejścia: 13.01.2016).

Pokrywka L., 2013, Monitoring zadtużenia miast wojewódz̨kich, Instytut Kościuszki.

Poniatowicz M., 2011, Ukrywanie dtugu jednostek samorzqdu terytorialnego w Polsce - problem realny cay marginalny?, [w:] Wyzwania dla samorzadón w nowej perspektywie europejskiej, VII Forum Samorzadowe, Zeszyty Naukowe Uniwersytetu Szczecińskiego nr 682, Ekonomiczne Problemy Usług, nr 76.

Poniatowicz M., Salachna J., Perło D., 2010, Efektywne zarzadzanie dtugiem w jednostkach samorzqdu terytorialnego, Wolters Kluwer Business, Warszawa.

Raport o polskich metropoliach - Poznań, 2015, www.pwc.pl (data wejścia: 01.07.2016).

Standar A., 2013, Analiza wskaźnikewa sytuacii finansowej gmin wojewódz̨twa wielkopolskiego, ,Journal of Agrobusiness and Rural Development", no. 20 (1).

Stanisz A., 2007, Praystepny kurs statystyki z zastosowaniem STATISTICA PL na praykładach z medycyny, t. 1-3, StatSoft Polska, Kraków.

Unia Metropolii Polskich, www.metropolie.pl (data wejścia: 14.07.2016). 
Ustawa z.dnia 27 sierpnia 2009 roku o finansach publicznych, Dz.U. z 2013 roku, poz. 885 z późn. zm.

Ustawa z dnia 5 czerwca 1998 roku o samorzadrie powiatonym, Dz.U. Nr 91, poz. 578 z późn. zm.

Wojciechowski E., 2012, Gospodarka samorzadu terytorialnego, Wydawnictwo Difin, Warszawa.

Wskaźniki do oceny sytuacii finansowej jednostek samorzadu terytorialnego, Ministerstwo Finansów, www.finanse.mf.gov.pl/budżet-panstwa/finanse-samorzadow/opracowania (data wejścia: 14.07.2016).

Wysocki F., 2010, Metody taksonomiczne w rozpoznawaniu typón ekonomicznych rolnictwa i obszarów wiejskich, Wydawnictwo Uniwersytetu Przyrodniczego w Poznaniu, Poznań.

Wysocki F., Lira J., 2003, Statystyka opisowa, Wydawnictwo Akademii Rolniczej w Poznaniu, Poznań.

Zadlużenie sektora finansów publicznych I kw. /2016, 2016, „Biuletyn Kwartalny”, 20, Ministerstwo Finansów, www.finanse.mf.gov.pl (data wejścia: 04.07.2016). 